\title{
OPTIMIZATION STUDIES ON PRODUCTION OF A SALT-TOLERANT PROTEASE FROM PSEUDOMONAS AERUGINOSA STRAIN BC1 AND ITS APPLICATION ON TANNERY SALINE WASTEWATER TREATMENT
}

\author{
Senthilkumar Sivaprakasam ${ }^{1}$, Balaji Dhandapani ${ }^{1}$, Surianarayanan Mahadevan $^{1 *}$ \\ ${ }^{1}$ Chemical Engineering Department, Central Leather Research Institute (CLRI), Adyar, Chennai - 20, Tamilnadu, India.
}

Submitted: June 25, 2010; Returned to authors for corrections: September 08, 2010; Approved: May 16, 2011.

\begin{abstract}
Treatment and safe disposal of tannery saline wastewater, a primary effluent stream that is generated by soaking salt-laden hides and skin is one of the major problems faced by the leather manufacturing industries. Conventional treatment methods like solar evaporation ponds and land composting are not eco-friendly as they deteriorate the ground water quality. Though, this waste stream is comprised of high concentration of dissolved proteins the presence of high salinity (1-6\% $\mathrm{NaCl}$ by wt) makes it non-biodegradable. Enzymatic treatment is one of the positive alternatives for management of such kind of waste streams. A novel salttolerant alkaline protease obtained from P.aeruginosa (isolated from tannery saline wastewater) was used for enzymatic degradation studies. The effect of various physical factors including $\mathrm{pH}$, temperature, incubation time, protein source and salinity on the activity of identified protease were investigated. Kinetic parameters $\left(\mathrm{K}_{\mathrm{m}}, \mathrm{V}_{\max }\right)$ were calculated for the identified alkaline protease at varying substrate concentrations. Tannery saline wastewater treated with identified salt tolerant protease showed $75 \%$ protein removal at $6 \mathrm{~h}$ duration and $2 \%(\mathrm{v} / \mathrm{v})$ protease addition was found to be the optimum dosage value.
\end{abstract}

Key words: COD, Enzymatic degradation, Leather Industry, Salt-tolerant, Waste treatment

\section{INTRODUCTION}

Leather industry is one of the major sectors of the Indian industrial base. It is recognized as one of the polluting industries. Sreeram and Ramasami (2003) characterized the different streams of effluents by leather industry and their impact on environment (18). Making of leather involves many wet processing stages, which may be broadly categorized in to pretanning and post tanning stages. The process details of the above are well reported in the literature (19). Pretanning operations is a source for generation of substantial quantity of effluents, which pose a threat to the environment. Since tanneries employ a sequence of batch processes and a wide range of raw materials, the effluents are complex in nature and with variation in characteristics from time to time, and processto-process. Tannery effluents have to be treated before they can be discharged to surface water (23).

Safe disposal of tannery saline wastewater generated during the first pretanning operation is one of the current problems faced by the tanning industries. Salt (sodium chloride 
$(\mathrm{NaCl}))$ is used to preserve the fresh skins from decomposition immediately after they are stripped in the slaughterhouse. The excess of salt has to be removed before the hides are further processed. This is done by soaking the hides in large quantity of water and this generates the first source of effluent. This tannery saline wastewater is characterized by high organic load, high suspended solids (sand, lime, hair, flesh, dung, etc.) and high salinity. Because of that high salt content, this wastewater is generally segregated and sent to Solar Evaporation Pans (SEPs). The presence of high concentrations of dissolved organic matter and Suspended Solids (SS) retards the rate of evaporation in SEPs. Tanneries require large land area to dispose the tannery saline wastewater and however, the salt obtained cannot be reused because of its high organic content. This salt is then discharged on open land and contributes to soil and water pollution. Therefore, treatment of this tannery saline wastewater, before sending it to SEPs is essential to remove the excess of organic matter, not only to accelerate the rate of evaporation, but also to reduce the odour of the effluent and improve the purity of the salt obtained (5). In an attempt to overcome some of the problems associated with traditional chemical and biological treatment of saline tannery wastewater treatment systems, present research work is focused first time to employ a salt tolerant enzyme (protease) as a primary agent for treatment. On comparison with traditional biological treatment of wastewater by microbial systems, enzymatic treatment is more advantageous for ease of their handling, storage and moreover the enzyme concentration is independent of microbial growth rate. Salt tolerant proteases are highly specific in their action and their activity can be better standardized in any harsh environment. Several researchers reported the novel characteristics of salt tolerant/resistant proteases identified from different microbes $(4,10,11,12,13$, 17, 20, 21, 22). Such kind of enzyme characteristics encourages their application in wastewater treatment systems. Enzymatic treatment was proved to be positive alternate as well as eco-friendly method for management of hazardous (1,
7) and dye house effluents $(8,15,24)$.

The purpose of the present research work is to perform the optimization of physical parameters such as temperature, inoculum size, $\mathrm{pH}$, salinity and incubation time on the production of a salt tolerant enzyme secreted by a salt tolerant $P$. aeruginosa strain isolated from commercial tannery saline wastewater. Additionally the use of identified protease on tannery saline wastewater treatment is also discussed in this paper.

\section{MATERIALS AND METHODS}

\section{Growth media}

Peptone enriched basal media containing $\left(\mathrm{g} \mathrm{l}^{-1}\right)$ : Peptone (Type IV), 10.0; ammonium sulphate $\left(\mathrm{NH}_{4}\right)_{2} \mathrm{SO}_{4}, 1.0$; potassium dihydrogen phosphate $\left(\mathrm{KH}_{2} \mathrm{PO}_{4}\right), 0.5$; magnesium sulphate $\left(\mathrm{MgSO}_{4}, 7 \mathrm{H}_{2} \mathrm{O}\right), 0.3$; calcium chloride $\left(\mathrm{CaCl}_{2}, 2 \mathrm{H}_{2} \mathrm{O}\right)$, 1.0; sodium chloride $(\mathrm{NaCl}), 1.0$; glycerol, $10.0 \mathrm{ml}$ was used for protease production in fermentor (14). Casein, Peptone, Bovine serum albumin, Nutrient agar and all other biochemicals were obtained from $\mathrm{M} / \mathrm{s}$ Himedia (Bangalore, India). All other reagents were purchased from Sd-fine chemicals (India).

\section{Bacterial Strain}

The bacterial strain (P. aeruginosa strain (BC 1)) used in this study was isolated from saline wastewater $(10 \% \mathrm{NaCl}$ by wt), collected from a commercial tannery at Chromepet, Chennai, India. This strain was proved to be a salt-tolerant bacterium with a high proteolytic activity. In addition, it is found to produce a salt-tolerant alkaline protease. P.aeruginosa strain isolated in this study has been characterized by both biochemical tests and 16S rRNA technique (16).

\section{Culture conditions}

Identified pure strain was maintained on nutrient agar 
slants at $4^{\circ} \mathrm{C}$ and sub cultured every 2 weeks. The pure strain was always stored at $-18^{\circ} \mathrm{C}$ in $30 \%$ glycerol stock solution.

\section{Preparation of enzyme}

Salt tolerant protease used for optimization and tannery saline wastewater degradation studies was obtained by cultivating $P$. aeruginosa aerobically in a peptone enriched basal media $(700 \mathrm{ml})$ using 11 capacity fermentor under preoptimized growth conditions. The values for optimized growth factors viz., $\mathrm{pH}$, temperature, aeration, stirrer speed and inoculum concentration were $7.0,37^{\circ} \mathrm{C}, 1 \mathrm{vvm}, 100 \mathrm{x}$ g and 2 $\%(\mathrm{v} / \mathrm{v})$ respectively. Presence of protease was confirmed by zone formation on incubated casein agar plate. Fermentation was performed till the culture reaches its stationary phase (where the enzyme activity was high) and culture filtrate was collected and used for protease extraction.

\section{Ammonium sulfate precipitation}

Ammonium sulfate is used to extract protease from the fermentation broth. $100 \mathrm{ml}$ of the supernatant was used for precipitation in $70 \%$ ammonium sulfate. All subsequent steps were carried out at $4^{\circ} \mathrm{C}$. The resulting precipitate was separated by centrifugation at $10000 \mathrm{x} \mathrm{g}$ for $30 \mathrm{~min}$ at $4^{\circ} \mathrm{C}$. The precipitate was dissolved in $20 \mathrm{mM}$ Tris- $\mathrm{HCl}(\mathrm{pH}$ 8.0) and kept for $24 \mathrm{~h}$ at $4^{\circ} \mathrm{C}$. The resulting mixture was again centrifuged at $10000 \mathrm{x} \mathrm{g}$ for $30 \mathrm{~min}$ at $4^{\circ} \mathrm{C}$ and the supernatant was dissolved in a minimum amount of $20 \mathrm{mM}$ Tris buffer, $\mathrm{pH}$ 8.0, containing $2 \mathrm{mM} \mathrm{CaCl}_{2}$, and dialyzed against the same buffer at $4^{\circ} \mathrm{C}$ overnight. The dialysate was lyophilized and stored at $4^{\circ} \mathrm{C}$. This dialysate sample was used for all the optimization and degradation studies.

\section{Assay of Protease activity}

Proteolytic (caseinolytic) activity was measured by slight modification of Anson method (2), where peptone was used as substrate instead of casein. Since peptone is a major protein constituent present in tannery saline waste stream, casein is replaced by peptone in this standard assay method. The reaction mixture consisted of $1.0 \mathrm{ml}$ of enzyme sample prepared by centrifuging the cell culture suspension in an ultra centrifuge at $10000 \mathrm{x} \mathrm{g}$ for $10 \mathrm{~min}$ and supernatant was obtained for protease assay. The reaction was initiated by the addition of $2.0 \mathrm{ml}$ peptone $[1.0 \%(\mathrm{w} / \mathrm{v})$ in $20 \mathrm{mM}$ borate buffer, $\mathrm{pH}$ 9.0]. The reaction mixture was then incubated in the incubator at $30^{\circ} \mathrm{C}$ for $15 \mathrm{~min}$ and terminated by the addition of $2.5 \mathrm{ml}, 10 \%(\mathrm{w} / \mathrm{v})$ trichloroacetic acid (TCA). A vortex mixer was used to insure complete mixing at various stages of these assay procedures. This mixture was further incubated at $30^{\circ} \mathrm{C}$ for $15 \mathrm{~min}$ and kept at room temperature for $30 \mathrm{~min}$. $0.5 \mathrm{ml}$ of the mixture was added with $5.0 \mathrm{ml}$ of $0.5 \mathrm{M} \mathrm{Na}_{2} \mathrm{CO}_{3}$ and kept at room temperature for $20 \mathrm{~min}$. $0.5 \mathrm{ml}$ of Folin - ciocalteau reagent: water (1:2) was added to yield a blue color. A 'blank' was prepared by the same procedure using distilled water and the absorbance was measured at $660 \mathrm{~nm}$ for all samples against blank. One unit of protease activity is defined as the amount of enzyme required to liberate one $\mu \mathrm{g}$ of tyrosine per min per $\mathrm{ml}$ under the standard assay conditions.

\section{Protein Estimation}

Protein content of tannery saline wastewater was estimated by Lowry's method (9) with a slight modification employing bovine serum albumin as the standard. Initially the samples were treated with $10 \%$ TCA solution (added in 1:1 ratio) for effective precipitation of dissolved protein in tannery saline wastewater and then the protein content of precipitate was estimated finally.

\section{EXPERIMENTS}

\section{Effect of pH and temperature on protease activity}

Effect of $\mathrm{pH}$ on dialyzed enzyme was studied in $\mathrm{pH}$ range from 5.0 to 11.0 under standard assay conditions $\left(30^{\circ} \mathrm{C}\right)$. To determine the optimum temperature for dialyzed protease, the activity values of protease were measured at various 
temperatures using casein as the substrate. The effect of temperature was studied by incubating the enzyme at wide range $\left(30-70^{\circ} \mathrm{C}\right)$. Appropriate aliquots were withdrawn at different time intervals and the residual activities determined at assay temperature.

\section{Effect of salinity}

Salinity effect was considered, as an important parameter needed to be optimized for the isolated protease, as it is to be employed for the tannery saline wastewater treatment. The saline concentrations were varied in accordance with characteristics of commercial tannery saline waste stream ( 0 to $7 \%, \mathrm{NaCl}$ by wt) at $30^{\circ} \mathrm{C}$.

\section{Effect of protein substrate}

Tannery saline wastewater is enriched with dissolved proteins and the type of protein determines the optimum protease activity. The activity of the isolated alkaline protease was examined with two different major protein sources namely peptone and casein.

\section{Determination of $K_{m}$ and $V_{\text {max }}$}

Values of Michaelis biokinetic constants $\mathrm{K}_{\mathrm{m}}$ and $\mathrm{V}_{\max }$ were determined for the hydrolysis of peptone by the dialyzed protease. A Lineweaver-Burk plot was drawn between the inverse of different concentrations of peptone and the reaction velocity to determine the biokinetic constant values for the dialyzed alkaline protease.

\section{Culture preparation for identification of Intracellular Protease}

Presence of intracellular protease secretion in P.aeruginosa was analyzed by ultrasonication method (6). The culture broth obtained from fermentor at $48 \mathrm{~h}$ duration was centrifuged at $10000 \mathrm{x} \mathrm{g}$ for $15 \mathrm{~min}$ in an ultracentrifuge. Supernatant was discarded and biomass residue obtained was used for ultrasonication studies.

\section{Ultrasonic cell disruption}

The harvested cell pellets ( $1 \mathrm{~g}$ by wt) was dissolved in 50 $\mathrm{ml}$ of $50 \mathrm{mM}$ Tris- $\mathrm{HCl}(\mathrm{pH} 8.0$ ) buffer. Disruption of cells was performed using an ultrasonicator (SONICS Vibracell) at 20 $\mathrm{kHz}$ equipped with a needle titanium probe of $10 \mathrm{~mm}$ diameter and $70 \mathrm{~mm}$ length. The disruption was $10 \mathrm{~s}$ with $15 \mathrm{~s}$ intervals in an ice bath (to prevent overheating) for duration of $60 \mathrm{~min}$. The samples were taken at 1, 3, 5, 10, 15, 30, 60 min intervals and protease activity assay was performed.

\section{Growth curve and protease production of P.aeruginosa strain}

The growth rate and protease production of P.aeruginosa were investigated on tannery saline wastewater $(\mathrm{pH} 7.0)$ in 250 $\mathrm{ml}$ conical flask at varying inoculum concentrations viz. $2 \%, 4$ $\%, 6 \%$ and $8 \%(\mathrm{v} / \mathrm{v})$. Samples were withdrawn at regular time intervals for protease production and biomass determinations. Biomass was determined by cell dry weight method.

\section{Tannery saline wastewater degradation}

Tannery Saline wastewater was collected from tannery near Pallavaram, Chennai and was characterized in terms of total soluble and suspended solids (TDS \& TSS), COD, BOD, Salinity, Total Protein and pH (3). The dialyzed protease obtained after lyophilization was used for degradation studies. It was added at varying concentrations $1 \%, 1.5 \%, 2 \%, 2.5 \%$ and $3 \%(\mathrm{w} / \mathrm{v})$ in the tannery saline wastewater and degradation was performed at optimized conditions. Mild shaking $(50 \mathrm{xg})$ was maintained in the shaking incubator to ensure uniform mixing and samples were collected at $1 \mathrm{~h}$ time interval for the analysis of total protein depletion and protease activity.

\section{RESULTS AND DISCUSSION}

\section{Effect of $\mathrm{pH}$ and temperature on protease activity}

Protease secreted from salt tolerant $P$. aeruginosa strain was found to be active over a broad range of $\mathrm{pH}$ values 
between 5.0 and 11.0 at $30^{\circ} \mathrm{C}$ with optimum $\mathrm{pH}$ of 9.0 for hydrolysis of peptone (Fig. 1). Based on this observation, the secreted protease could be classified as an alkaline protease. As shown in Fig. 1, at acidic $\mathrm{pH}(\mathrm{pH} 5.6), 14 \%$ reduction of the enzyme activity was observed compared to $\mathrm{pH}$ 7.0. At $\mathrm{pH} 9.0$, the protease activity was increased by $9.8 \%$ as compared to $\mathrm{pH} 7.0$. Further increase in $\mathrm{pH}$ to strong alkaline range $(>\mathrm{pH} 10.0)$ caused a sudden fall in enzyme activity up to $35 \%$. Optimum $\mathrm{pH}$ range was found to be between 7.0 and 9.0 for high protease activity.
Generally the $\mathrm{pH}$ of the tannery saline wastewater was found to be either neutral or slightly alkaline condition which favors the potential usage of the isolated protease for degradation studies.

Optimum activity of the dialyzed enzyme was exhibited at $35^{\circ} \mathrm{C}$. Further increase in temperature $\left(40-70^{\circ} \mathrm{C}\right)$ caused drop in enzyme activity (Fig. 2). In India, wastewater treatment plants generally operate at ambient temperature, which is in the range of $30-37^{\circ} \mathrm{C}$. Hence the isolated protease could be used for an effective degradation of the tannery saline wastewater.

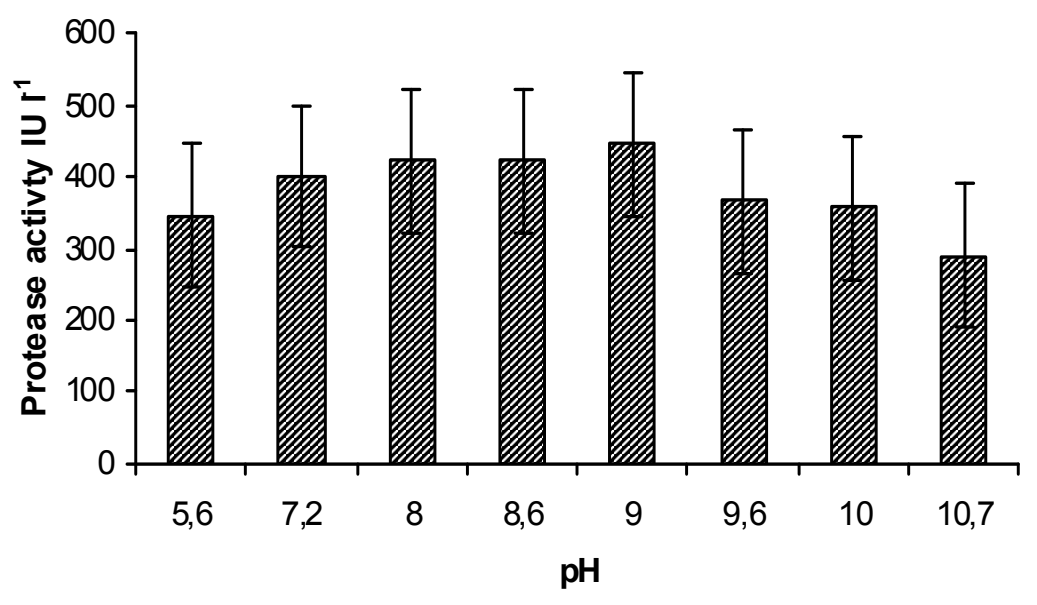

Figure 1. Optimum $\mathrm{pH}$ of extracted alkaline protease. Optimum $\mathrm{pH}$ was obtained by incubating the enzyme with substrate at different $\mathrm{pH}$ values. The buffers used were $0.03 \mathrm{M}$ phosphate ( $\mathrm{pH}$ 6.0-8.0); 0.1 M Tris- $\mathrm{HCl}$ ( $\mathrm{pH}$ 8.0-9.0); 0.1 M glycine- $\mathrm{NaOH}$ (pH 9.0-10.0) and $0.03 \mathrm{M}$ borax $-\mathrm{NaOH}(\mathrm{pH} 9.5-11)$. The activity at $\mathrm{pH} 9.0$ is found as optimum.

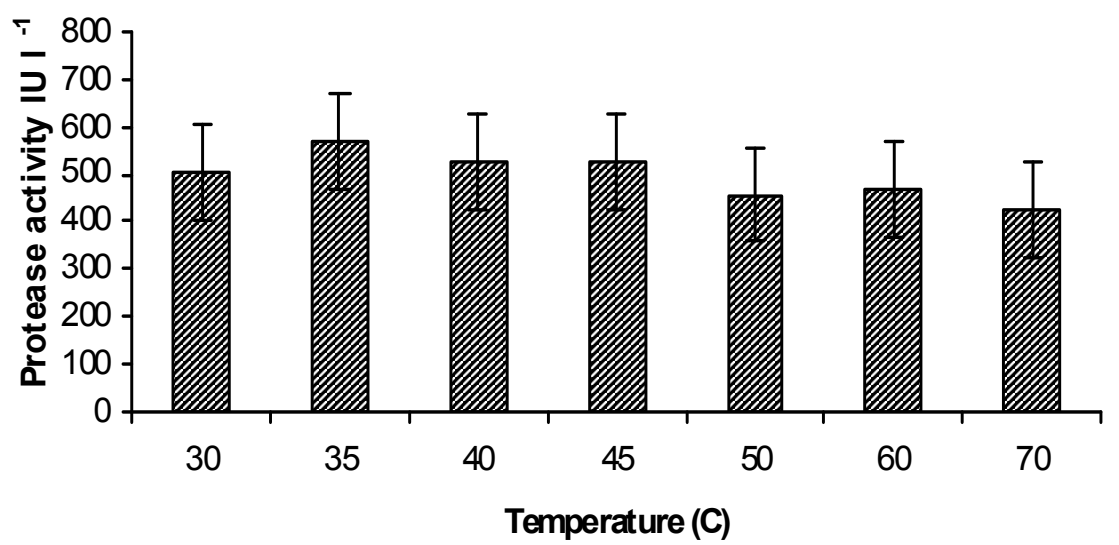

Figure 2. Optimum temperature of alkaline protease. The extracted enzyme was incubated with the substrate at different temperatures. The activity at $35^{\circ} \mathrm{C}$ has been taken as optimum. 


\section{Salinity effect}

The effect of salinity on protease activity is represented in Fig.3. Even though a considerable amount of protease activity was observed at high saline conditions ranging from $4 \%$ to $7 \%$, optimum activity was observed at $2 \%$ salt concentration and increase in salinity level to $4 \%$ ( $\mathrm{NaCl}$ by wt) resulted in loss of activity to $20 \%$. This illustrates the proteolytic activity of isolated protease, as the waste stream is mainly composed of dissolved proteins.

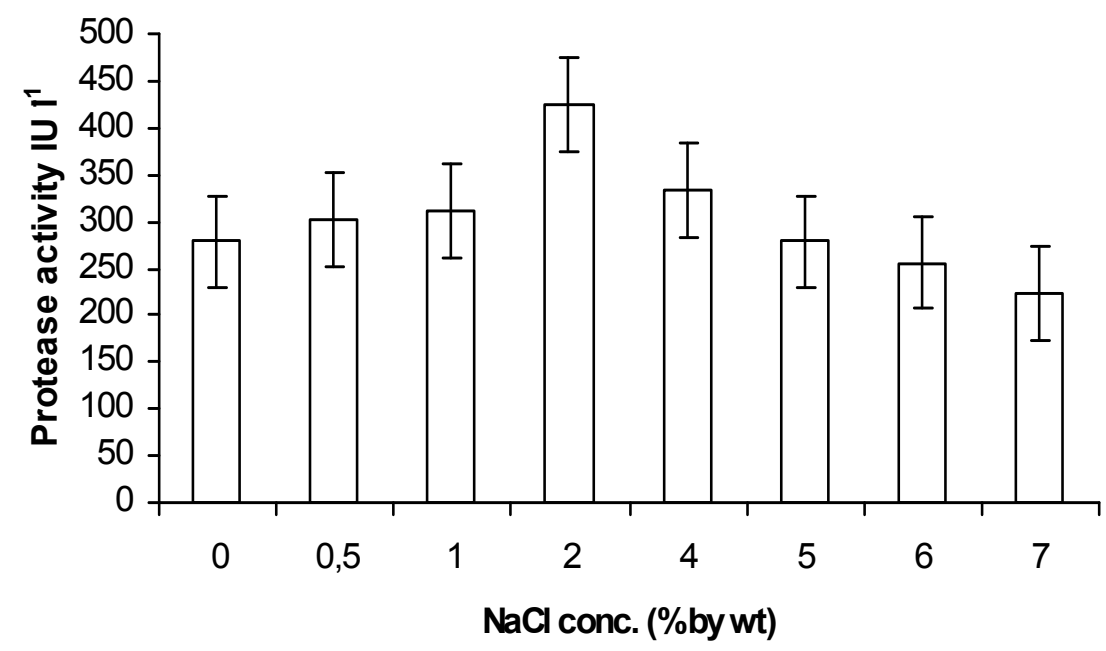

Figure 3. Salinity effect on protease activity. Extracted enzyme was incubated at varying salinity concentrations $(0-7 \% \mathrm{NaCl}$ by wt $)$ at optimized conditions. Optimum activity is found at $2 \%$ salinity conc. showing that isolate protease is halo - tolerant.

\section{Effect of protein substrate}

The results of the effect of protein source on protease activity are summarized in Table 1. Both peptone and casein were found to enhance protease activity and a high protease activity was detected for peptone $\left(256.3 \mathrm{IU} \mathrm{l}^{-1}\right)$. Peptone caused a slight increase of protease activity to $9 \%$ compared to casein. This favors the ease of application of dialyzed protease for tannery saline wastewater degradation, as the waste stream is mainly composed of dissolved proteins only.

Table 1. Effect of protein source (Substrate) on protease activity of alkaline protease obtained from P.aeruginosa

\begin{tabular}{|c|c|c|c|c|c|}
\hline S. No & Substrate & Enzyme Source & Absorbance at $660 \mathrm{~nm}$ & $\begin{array}{c}\text { Product } \\
\text { Concentration }\left(\mu \mathrm{g} \mathrm{l}^{-1}\right)\end{array}$ & $\begin{array}{c}\text { Enzyme* activity } \\
\left(\text { IU l l }{ }^{-1}\right)\end{array}$ \\
\hline 1. & Peptone & Dialyzed sample & 0.023 & 19 & 256.27 \\
\hline 2. & Casein & Dialyzed sample & 0.021 & 17 & 233.98 \\
\hline
\end{tabular}

\section{$K_{m}$ and $V_{\max }$ determination}

The dialyzed protease was further investigated for its catalytic activity by determining $\mathrm{K}_{\mathrm{m}}$ and $\mathrm{V}_{\text {max }}$ values using peptone as a substrate. The values of $K_{m}$ and $\mathrm{V}_{\max }$ were observed as $13.55 \mathrm{~g} \mathrm{l}^{-1}$ and $\mathrm{V}_{\max }$ of $45.35 \mathrm{~g} \mathrm{l}^{-1} \mathrm{~min}^{-1}$ respectively. This high $\mathrm{V}_{\max }$ value shows the enhanced activity of the dialyzed enzyme and its potential usage in proteolytic reactions.

\section{Ultrasonication studies}

Table 2 gives information on results obtained from ultrasonication studies on cell suspensions of P.aeruginosa for the time duration of $0-60 \mathrm{~min}$. There was no appreciable change in the product concentration for different time intervals. 
Protease activity estimation also proves that there is no marked increase in enzyme activity levels till $60 \mathrm{~min}$ duration. Ultrasonication results confirm the absence of intracellular protease secretion for P.aeruginosa and this further adds the importance of isolation of extracellular alkaline protease and its major role in proteolytic reactions.

Table 2. Effect of ultrasonication on protease activity of P.aeruginosa

\begin{tabular}{ccccc}
\hline S. No & Time in $\mathbf{m i n}$ & Absorbance at 660nm & Product Concentration $\left(\boldsymbol{\mu g} \mathbf{~ I}^{-\mathbf{1}}\right)$ & ${\text { Enzyme activity }\left(\mathbf{I U} \mathbf{~ I}^{-\mathbf{1}}\right)}$ \\
\hline 1. & 0 & 0.202 & 17 & 2250.70 \\
2. & 1 & 0.220 & 18 & 2451.25 \\
3. & 3 & 0.221 & 18 & 2462.40 \\
4. & 5 & 0.221 & 18 & 2462.40 \\
5. & 10 & 0.226 & 21 & 2518.11 \\
6. & 15 & 0.234 & 19 & 2607.24 \\
7. & 30 & 0.222 & 18 & 2473.54 \\
8. & 60 & 0.213 & 17 & 2373.26 \\
\hline
\end{tabular}

\section{Growth rate and protease secretion of P.aeruginosa in tannery} saline wastewater

The composition of tannery saline wastewater was given in Table 3. A study was performed to determine the growth rate and protease production of $P$. aeruginosa strain in tannery saline wastewater with respect to time. Growth rate determined at different time intervals for varying inoculum levels viz. $2 \%, 4 \%$, $6 \%$ and $8 \%(\mathrm{v} / \mathrm{v})$ is shown in Fig. 4. Maximum growth rate was observed after $32 \mathrm{~h}$ incubation for all inoculum concentrations. In tannery saline wastewater the exponential phase commenced after $20^{\text {th }} \mathrm{h}$ and continued for $16 \mathrm{~h}$ duration. There is no appreciable difference in growth rates for change in inoculum concentrations. Protease activity profiles obtained from tannery saline wastewater for varying inoculum levels is given in Fig 5. Protease production was detected

in the

exponential phase $(20 \mathrm{~h})$ and it increased to its optimum value at $32 \mathrm{~h}$ incubation. Similar to biomass growth, inoculum concentration also did not have effect on protease secretion.

Table 3. Characteristics of tannery saline wastewater

\begin{tabular}{cc}
\hline Parameter & Composition \\
\hline COD $\left(\mathrm{mg} \mathrm{l}^{-1}\right)$ & 1331 \\
BOD $\left(\mathrm{mg} \mathrm{l}^{-1}\right)$ & 384 \\
TSS $\left(\mathrm{mg} \mathrm{l}^{-1}\right)$ & 5436 \\
TDS $\left(\mathrm{m} \mathrm{l} \mathrm{l}^{-1}\right)$ & 7972 \\
Chloride $\left(\mathrm{mg} \mathrm{l}^{-1}\right)$ & 999 \\
Protein $\left(\mathrm{mg} \mathrm{l}^{-1}\right)$ & 580 \\
$\mathrm{pH}$ & 7.45
\end{tabular}

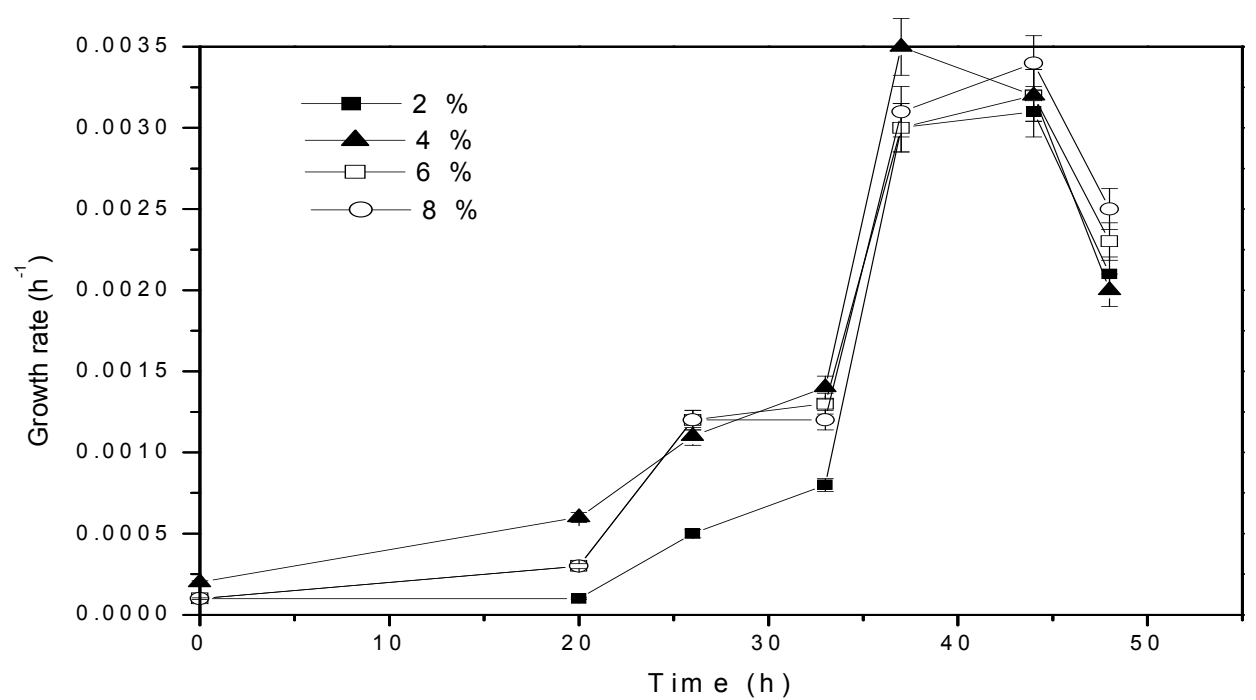


Figure 4. Growth rate of P.aeruginosa in tannery saline wastewater for varying innoculum concentrations viz. $2 \%, 4 \%, 6 \%$, $8 \%(\mathrm{v} / \mathrm{v})$ under optimized conditions.

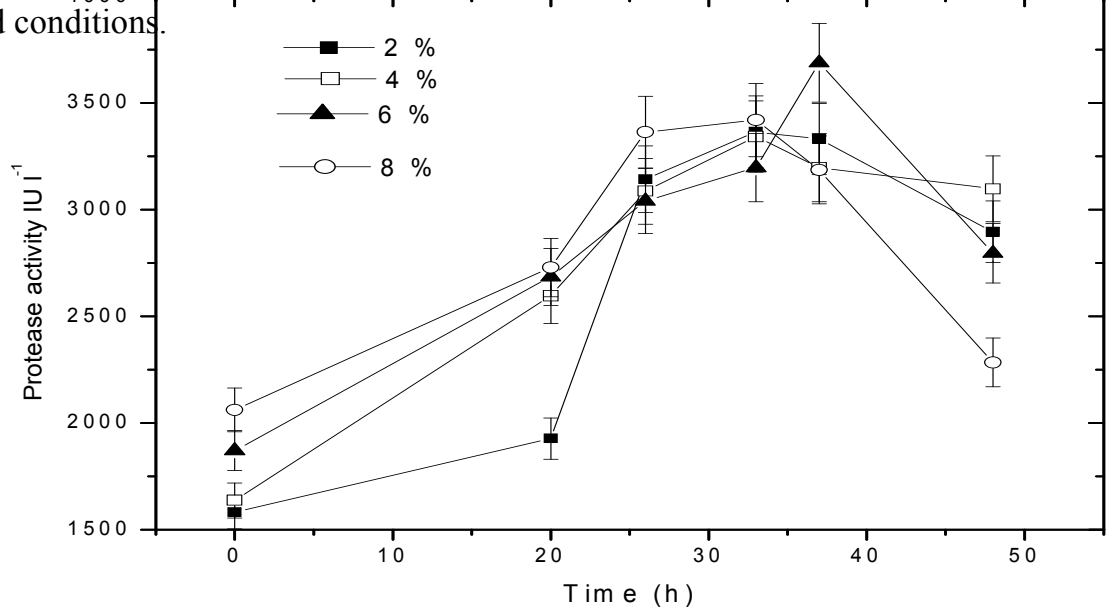

Figure 5. Protease activity of P.aeruginosa in tannery saline wastewater for varying inoculum concentrations viz. $2 \%, 4 \%, 6 \%$, $8 \%(\mathrm{v} / \mathrm{v})$ under optimized conditions.

\section{Tannery saline wastewater degradation}

Fig. 6 depicts the total protein degradation profile of tannery saline wastewater by the alkaline protease added at varying concentrations viz. $1 \%, 1.5 \%, 2 \%, 2.5 \%$ and $3 \%(\mathrm{v} / \mathrm{v}) .2 \%$ $(\mathrm{v} / \mathrm{v})$ of protease was found to be optimum dosage value for efficient degradation of dissolved proteins present in saline waste stream. About $75 \%$ degradation was achieved within 6 h duration at high saline condition ( $6 \% \mathrm{NaCl}$ by wt), which facilitates the use of the identified protease for the treatment of commercial tannery saline wastewater. Increasing the protease dosage from 2 $\%$ to $2.5 \%$ showed a decrease in protein degradation efficiency

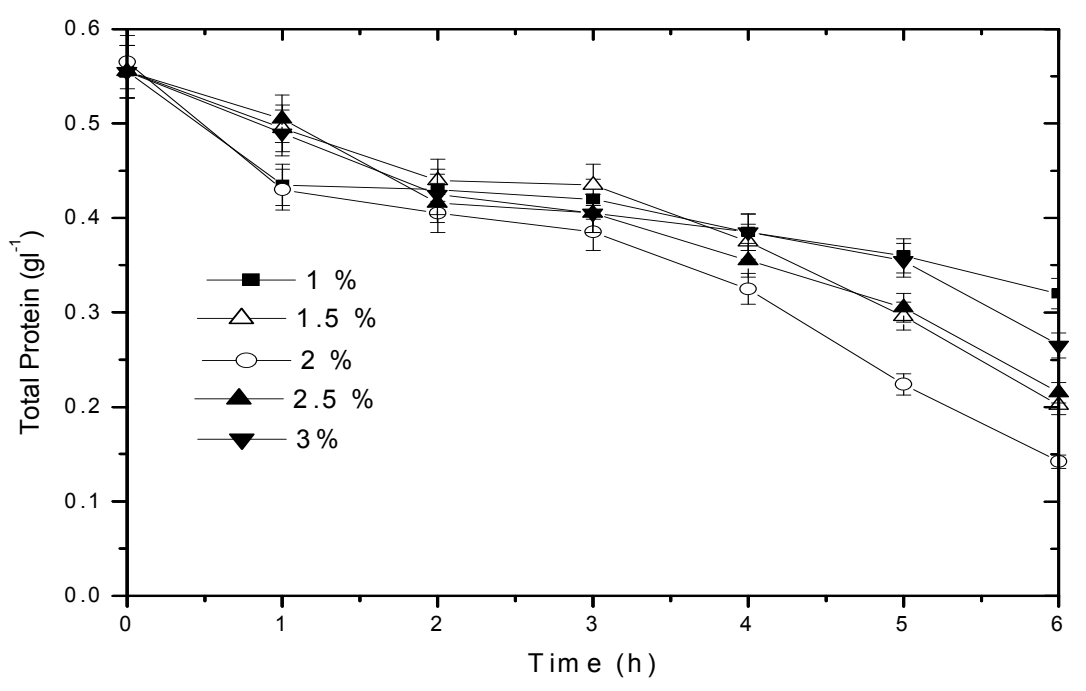

(by $14 \%$ ) from $75 \%$ to $61 \%$. This may be due to inhibition effect exhibited by the presence of excess amount of protease concentration for an available protein (substrate) present in wastewater. This fact is further confirmed from the protease activity profile (Fig. 7) observed for different protease dosage values viz. $1 \%, 1.5 \%, 2 \%, 2.5 \%$ and $3 \%(v / v)$. From Fig. 7 , it can be observed that a high protease activity $\left(65000 \mathrm{IU} \mathrm{l}^{-1}\right.$ at $0 \mathrm{~h}$ and $20385 \mathrm{IU} \mathrm{l}^{-1}$ at $\left.6 \mathrm{~h}\right)$ was observed for $2 \%(\mathrm{w} / \mathrm{v})$ protease dosage compared to other dosage values $(1 \%, 1.5 \%, 2.5 \%$ and 3 $\% \mathrm{w} / \mathrm{v})$. Hence $2 \%(\mathrm{w} / \mathrm{v})$ was found to be optimum dosage value for effective degradation of proteins present in tannery saline wastewater. It could be also observed from Fig.7, that protease activity decreases with time and this further suggests the protein (substrate) depletion in tannery saline wastewater due to enzymatic treatment.

Figure 6. Enzymatic degradation studies: Total protein removal in tannery saline wastewater by alkaline protease added at varying dosages viz. $1 \%, 1.5 \%, 2 \%, 2.5 \%$ 


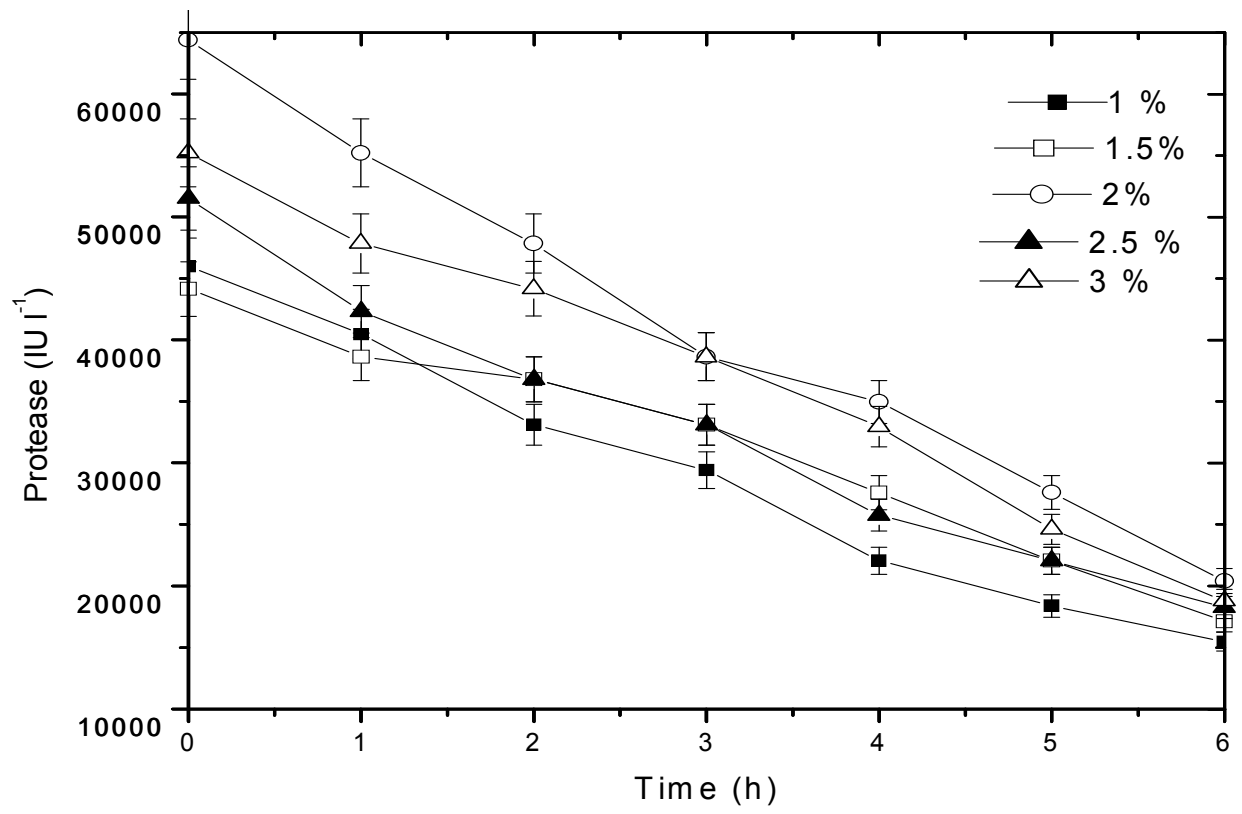

Figure 7. Enzymatic degradation studies: Protease activity of alkaline protease added at varying dosages viz. $1 \%, 1.5 \%, 2 \%, 2.5$ $\%$ and $3 \%(\mathrm{v} / \mathrm{v})$ under optimized conditions in tannery saline wastewater

\section{CONCLUSIONS}

A salt tolerant protease secreted by P.aeruginosa (isolated from tannery saline waste) was purified. Effect of physical factors such as $\mathrm{pH}$, temperature, salinity, and protein substrate were studied effectively and optimized for a maximum protease activity. Michaelis-Menten biokinetic constants $\left(\mathrm{K}_{\mathrm{m}}\right.$, $\mathrm{V}_{\max }$ ) were calculated to analyze the substrate affinity behavior for the identified alkaline protease. Batch level enzymatic degradation studies were performed for the treatment of tannery saline wastewater using alkaline protease under optimized conditions. A maximum treatment efficiency of 75 $\%$ Protein removal (at $6 \%$ saline conc.) was achieved in $6 \mathrm{~h}$ duration with $2 \%(\mathrm{w} / \mathrm{v})$ of protease dosage. The results obtained in the study illustrate the viability of using a halotolerant alkaline protease for treatment of tannery saline wastewater. Further studies will focus on using an immobilized column for treatment of tannery saline wastewater in order to reduce the amount of enzyme dosage as well as cost involved in its operation.

\section{ACKNOWLEDGEMENT}

Authors Dr. SS and Mr. BD is grateful to CSIR, New Delhi for the SRF fellowship. The author thanks the Director, CLRI for his kind permission to publish this work. The authors also wishes to express their gratitude to Prof. Gandhi for his useful suggestion and Prof. N.R Rajagopal for his constant encouragement.

\section{REFERENCES}

1. Alcalde, M.; Ferrer, M.; Plou, F.J.; Ballesteros, A. (2006). Environmental biocatalysis: from remediation with enzymes to novel green processes. Trends in Biotechnol. 24 (6): 281-287.

2. ANSON, M.L. (1938). THE ESTIMATION OF PEPSIN, TRYPSIN, PAPAIN AND CAthepsin With hemoglobin. J. GEN. Physiol. 22 (1) : 79-89.

3. Clesceri, A., Greenberg, L.; Eaton, A. (1998). Standard Methods for the Analysis of Water and Wastewater in: American Public Health Association, Alexandria, VA.

4. Dodia, M. S.; Rawal, C. M.; Bhimani, H. G.; Joshi, R. H.; Khare, S.K.; Singh. S.P. (2008). Purification and stability characteristics of an alkaline serine protease from a newly isolated Haloalkaliphilic bacterium sp. $\mathrm{AH}-$ 6. J. Ind. Microbiol. Biotech. 35 (2) : 121-132. 
5. Groenestijn, J.W.; Langerwerf J.S.A.; Lucas, M. (2002). Reducing environmental emissions in tanneries. J. Env. Sci. Health Part A: Toxic/Haz. Subs. Env. Engg. 37 (4) : 737-743.

6. Ho, C.W.; Chew, T.K.; Ling, T.C.; Kamaruddin, S.; Tan, W.S.; Beng, T.T. (2006). Efficient mechanical cell disruption of Escherichia coli by an ultrasonicator and recovery of intracellular hepatitis B core antigen. Proc. Biochem. 41 (8) : 1829-1834.

7. Kauffmann, C.; Petersen, B.R.; Bjerrum, M.J.(1999). Enzymatic removal of phenols from aqueous solutions by Coprinus cinereus peroxidase and hydrogen peroxide. J.Biotechnol. 73 (1) : 71-74.

8. Lan, J.; Huang, X.; Hu, M.; Li, Y.; Qu, Y.; Gao, P.; Wu, D. (2006). High efficient degradation of dyes with lignin peroxidase coupled with glucose oxidase. J. Biotechnol. 123 (4) : 483-490.

9. Lowry, O.H.; Rosebrough, N.J.; Farr, A.L.; Randall, R.J. (1951). Protein measurement with the folin phenol reagent. J.Biol.Chem.193 (1): $265-$ 275.

10. Mital, S.; Dodia, M.; Rupal, H.; Joshi, R.H.; Patel, R.; Singh, S.P. (2006). Characterization and Stability of Extracellular Alkaline Proteases from Moderately Halophilic and alkaliphilic Bacteria Isolated from Saline Habitat of Coastal Gujarat, India. Braz. J. Microbiol. 37 (3) : 276282.

11. Nowlan, B.; Dodia, M.S.; Singh, S.P.; Patel, B.K.C. (2006). Bacillus okhensis sp. nov., a halotolerant and alkalitolerant bacterium from an Indian salt pan. Int. J. Syst. Evol. Microbiol. 56 (5) : 1073-1077.

12. Patel, R.; Dodia, M.; Singh, S. P. (2006). Purification and characterization of alkaline protease from a newly isolated Haloalkaliphilic Bacillus sp. Proc. Biochem. 41 (9) : 2002-2009.

13. Patel, R. K.; Dodia, M. S.; Joshi, R. H.; Singh, S. P. (2006). Production of extracellular halo-alkaline protease from a newly isolated Haloalkaliphilic Bacillus sp. isolated from seawater in Western India. World J. Microbiol. Biotechnol. 22 (4) : 375-382.

14. Rahman, R.N.Z.A.; Geok, L.P.; Basri, M.; Salleh, A.B. (2005). Physical factors affecting the production of organic solvent-tolerant protease by
Pseudomonas aeruginosa strain K. Biores. Technol. 96 (4): 429-436.

15. Ruggaber, T.P.; Talley, J.W. (2006). Enhancing Bioremediation with Enzymatic Processes: A Review', Pract. Period. Haz. Tox. Rad. Waste Managt. 10 (2) : 73-85.

16. Senthilkumar, S.; Surianarayanan, M.; Sudharshan, S; Swaminathan, G. (2008) Batch studies on biological treatment of tannery saline wastewater by identified halotolerant bacterial strains. Microb. Cell Fact. 7(15): 1-7.

17. Sinha, R.; Joshi, R.H.; Dodia, M. S.; Singh, S.P. (2007). Production, purification and characterization of an alkaline protease from an alkaliphilic bacillus sp. J. Cell Tiss.Res. 7: 1031-1037.

18. Sreeram, K.J.; Ramasami, T. (2003). Sustaining tanning process through conservation, recovery and better utilization of chromium. Res. Conserv. Recyc. 38 (3):185-212.

19. Thanikaivelan P.; Raghava Rao, J.; Unni Nair, B.; Ramasamy, T. (2005). Recent Trends in Leather Making: Processes, Problems, and Pathways. Crit. Rev. Env. Sci. Technol. 35 (1) : 37-79.

20. Thumar, J.; Singh, S.P. (2007). Two - step purification of a highly thermostable alkaline protease from salt-tolerant alkaliphilic Streptomyces clavuligerus strain Mit-1. J. Chromat. B. 854 (1-2):198203.

21. Thumar, J.; Singh, S.P. (2007). Secretion of an alkaline protease from a salt- tolerant and alkaliphilic, Streptomyces clavuligerus strain Mit-1. Braz. J. Microbiol. 38 (4): 766-772.

22. Vasavada, S.; Thumar, J.; Singh, S. P. (2006). Secretion of a potent antibiotic by salt-tolerant and alkaliphilic actinomycete Streptomyces sannanensis strain RJT-1. Curr. Sci. 91 (10):1393-1397.

23. Wiegant, W.M.; Kalker, T.J.J.; Sontakke, V.N.; Zwaag, R.R. (1999). Full-scale experience with tannery water management: an. integrated approach. Water Sci.Tech. 39 (5) :169-176.

24. Zamora, P.P.; Pereira, C.M.; Tiburtius, E.R.L.; Moraes, S.G.; Rosa, M.A.; Minussi, R.C.; Durán, N. (2003). Decolorization of reactive dyes by immobilized laccase. Appl. Cat. B: Env. 42 (2) : 131-144.

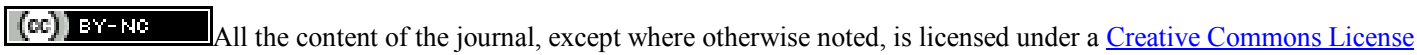

